\title{
Gordon Mathews, Ghetto at the Center of the World: Chungking Mansions, Hong Kong
}

Hong Kong University Press 2011, 241 pp.

N. Jayaram

\section{OpenEdition}

\section{Journals}

Electronic version

URL: http://journals.openedition.org/chinaperspectives/5907

DOI: $10.4000 /$ chinaperspectives.5907

ISSN: 1996-4617

\section{Publisher}

Centre d'étude français sur la Chine contemporaine

Printed version

Date of publication: 4 June 2012

Number of pages: 93-94

ISSN: 2070-3449

\section{Electronic reference}

N. Jayaram, "Gordon Mathews, Ghetto at the Center of the World: Chungking Mansions, Hong Kong ", China Perspectives [Online], 2012/2 | 2012, Online since 30 June 2012, connection on 21 September 2020. URL : http://journals.openedition.org/chinaperspectives/5907 ; DOI : https://doi.org/10.4000/ chinaperspectives.5907

This text was automatically generated on 21 September 2020.

(c) All rights reserved 


\section{Gordon Mathews, Ghetto at the Center of the World: Chungking Mansions, Hong Kong}

Hong Kong University Press 2011, 241 pp.

\section{N. Jayaram}

After being posted as correspondent of an Indian news agency in Beijing in 1988, I made my first trip to Hong Kong in 1989 to buy some equipment and was told by the few Indians living in the Chinese capital then that Chungking Mansions was the place to go. I stayed in one of the socalled guesthouses there for a few days and swore to myself never to set foot in the building ever again. It was not that the guesthouse was bad; on the contrary, it was kept reasonably clean by the Filipino partner of the Indian man who ran it. But it was the windowlessness of the place and the long wait for tiny lifts to upper floors that made it claustrophobic and unappealing. With obvious exaggeration I took to saying that nuclear fallout would have difficulty penetrating that maze of a building. And on my first

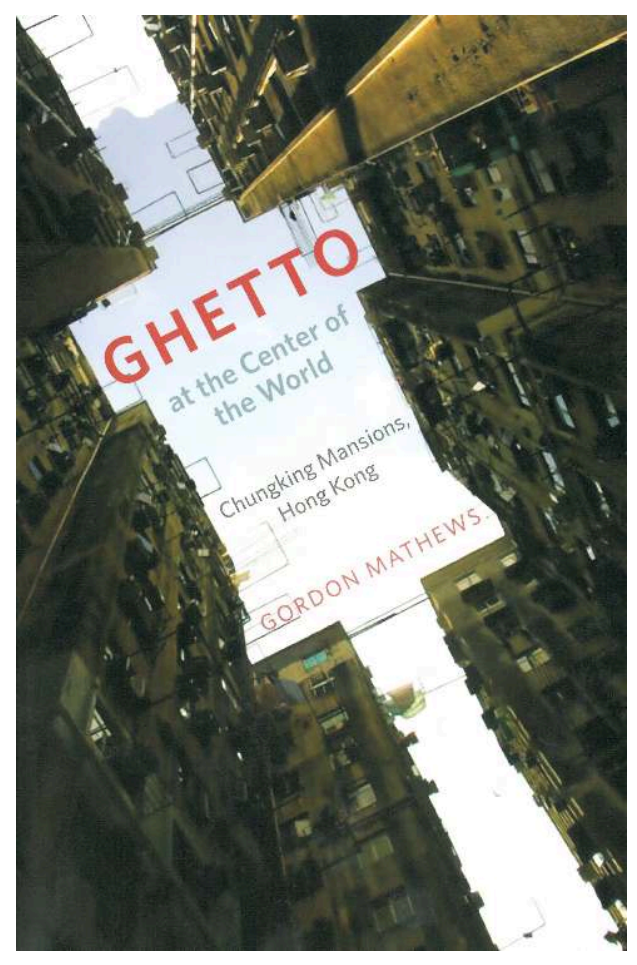
foolish attempt at comparing prices of electrical and electronic goods in some ground floor shops then, a couple of strong words of abuse in Urdu/Punjabi were hurled at me - by a Chinese shop assistant. 
2 Eventually, though, a year or two after moving to Hong Kong in 1995, I gravitated back to the building for occasional meals, which are somewhat cheaper than in the so-called Indian restaurants elsewhere in Hong Kong. Some of the stores began stocking more food articles from the subcontinent. A few local products sold at ever increasing prices in Hong Kong's grocery chains are available at a slightly lower price in Chungking Mansions.

3 The building's proximity to the Cultural Centre, venue of music concerts and arts and film festivals, makes it a draw for the less squeamish members of the artsy set. I once heard snippets of a conversation at a table next to mine in a Chungking Mansions restaurant among some delegates to the annual Hong Kong International Film Festival, about the malevolent influence of Florida's Cuban Americans on Washington's policy towards Havana!

4 I was reminded of this while reading about a similar situation - not in terms of content of discussion but of language - in this book on Chungking Mansions by Gordon Mathews, professor of anthropology at the Chinese University of Hong Kong. He says that once he, an American, ended up conversing with a Bangladeshi and a Cameroonian at a dinner table in the building, in Japanese (pp. 96-97).

5 Mathews describes Chungking Mansions as the centre of "low-end globalisation" featuring petty traders, asylum seekers, itinerant workers, small-time entrepreneurs, tourists, and the unavoidable gamut of sex workers and substance abusers. He defines "low-end globalisation" as "the transnational flow of goods involving relatively small amounts of capital and informal, sometimes semilegal or illegal, transactions commonly associated with 'the developing world'. This is the globalization of African traders returning to their homelands clutching a few hundred phones in their luggage, and of South Asian temporary workers bringing home to their families a few hundred dollars of needed money and extraordinary tales from a world their families can only imagine" (pp. 19-20).

6 If Hong Kong as a whole has long been an entrepot between China and the rest of the world, Chungking Mansions has functioned as a mini-entrepot, servicing - and being serviced by - the somewhat more indigent people of the world, those who are looking for cheap mobile phones and clothes from China.

7 The building is an informal United Nations of sorts. Mathews says he has counted 129 nationalities in its guesthouse logs and in his own meetings with people (p. 7). It might not be unrealistic to assume total all-time footfalls from people of 150 countries or more. The people in the building are mostly tourists, businesspeople, migrant workers, local shoppers and diners (themselves representing many different nationalities and national origins), and asylum seekers. Mathews says even the last-named "are among the elite of their home societies" because they had "enough money to fly to Hong Kong, something that the vast majority of their compatriots cannot ever do" (p. 102).

Many readers might feel ill-at-ease with what seems to be the author's tacit defence of "neoliberalism" at work in Chungking Mansions. "Anthropological literature typically depicts neoliberalism as a profound evil, representing the forces of rampant global capitalism destroying all possibility of resistance," he notes. "From a macroscopic perspective it is no doubt true that neoliberalism adversely affects the world. But in the small world of Chungking Mansions, the effects of neoliberalism seem largely benign" 
(p. 213). Mathews cites numerous examples of underpaid and exploited workers in the building, whose desire is to one day become bosses themselves.

As Mathews is careful to note, however, the people in Chungking Mansions are there by their own volition. In that sense, it is a self-selecting sample that he has studied. These are not trade unionists or other kinds of activists, and even if they were politically active back home, once in Hong Kong and in Chungking Mansions, they have to play by the narrow sets of rules - formal and informal - that govern life there. One is therefore left wondering why Mathews makes so much of the "neoliberal" aspect of the building's functioning.

10 Another aspect that occasionally jars is his harping on national divisions among people in the building. A couple of sentences of his that have been picked up in numerous press reports about the book and his work on Chungking Mansions are quotes from a Pakistani about Indians, to the effect that he does not like them but cannot afford to fight (p. 101). But surely there would have been examples of abiding friendships and comradely exchanges as well, especially as they have shared languages and cultural and culinary tastes among other things. They are equally at the receiving end of discriminatory treatment from some Chinese people and Westerners in Hong Kong. Many Indians and Pakistanis tend to support each other's cricket teams when they are playing a third country team, for instance.

That said, Mathews clearly has abiding sympathy for all the various types of people in the building. He is a committed intellectual and has held classes for asylum seekers, has intervened in disputes, and has even interceded with the police and other authorities in Hong Kong to help people in the building. He has spent many long days and nights studying all that goes on, and the people who live, work, and pass through there, together with a small battalion of his students. And he is concerned about the building's future, given the pressure from rising land value and the increasing sinicisation of Hong Kong.

Periodically, some commentators writing in Hong Kong newspapers have called for the building to be torn down. In a way, this book by Gordon Mathews shows up the frivolity of their stand by highlighting the richness of life in and around Chungking Mansions. Incidentally, the building recently underwent another round of refurbishment indicating, perhaps, that it is not ready to be condemned just yet - and copies of the book were distributed to mark the event.

Quite apart from being an important addition to anthropological literature - and the book is replete with fascinating accounts of how Mathews and his researchers went about interviewing people in the building and the difficulties they encountered - the book is certain to figure prominently among those that travellers to Hong Kong will be recommended to read if they want to get a real feel of the place. It is thus likely to appeal equally to academics and to lay readers. 


\section{AUTHOR}

\section{N. JAYARAM}

A journalist in Bangalore, India, he had previously worked in Hong Kong, Beijing, and New Delhi. 